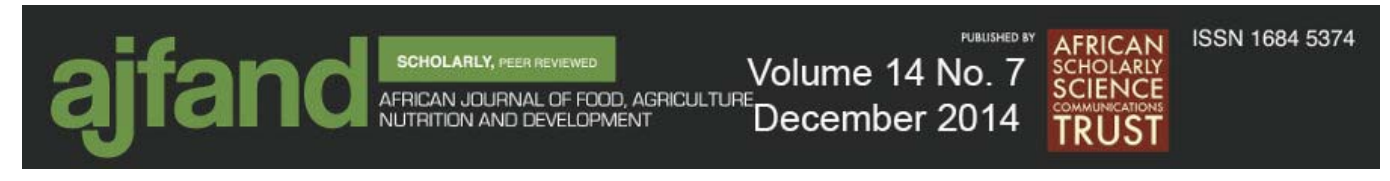

\title{
THE VALUE OF ENHANCING NUTRIENT BIOAVAILABILITY OF LENTILS: THE SRI LANKAN SCENARIO
}

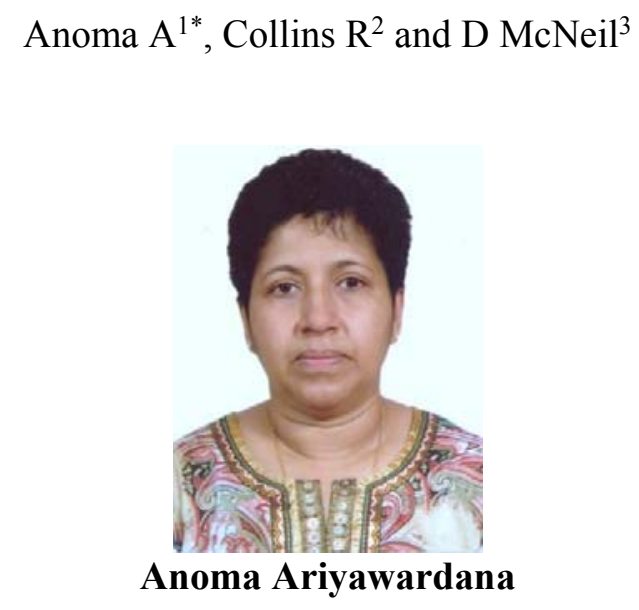

*Corresponding author email: a.ariyawardana@,uq.edu.au

${ }^{1}$ Senior Lecturer in Agribusiness Management, School of Agriculture and Food Sciences, Faculty of Science, University of Queensland, Gatton, Queensland, 4343, Australia

${ }^{2}$ Professor and Group Leader in Agribusiness, School of Agriculture and Food Sciences, Faculty of Science, University of Queensland, Gatton, Queensland, 4343, Australia

${ }^{3}$ Professor and Chair of Agricultural Science, Tasmanian Institute of Agriculture, University of Tasmania, Hobart, Tasmania, 7001, Australia. 


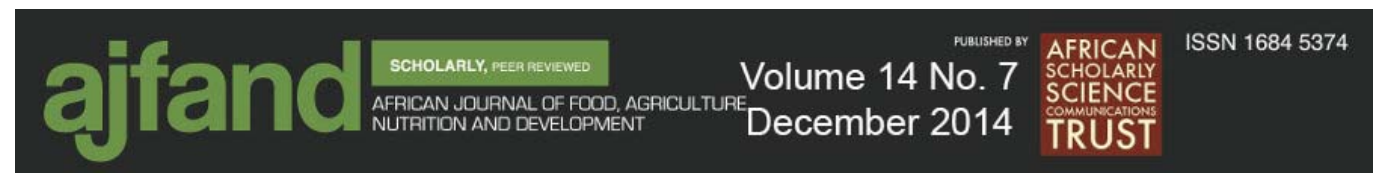

\section{ABSTRACT}

Lentil (Lens culinaris Medic.) is a pulse crop that belongs to the family Leguminosae. Lentils are rich in proteins, have 18 of the 20 amino acids including all 8 essential amino acids and provide a number of essential minerals and vitamins. Thus, lentils occupy an important place in the human diet, especially in developing countries, as a rich source of protein, vitamins and minerals. Although in many developing countries in Asia rice contributes significantly to human daily energy and nutritional requirements, its amino acid profile shows that rice lacks some essential amino acids. Therefore, given their rich composition of amino acids, lentils could act as an ideal supplement for rice-based diets. Although all red lentils are imported, they are the most widely consumed pulse among Sri Lankans. Red lentil consumption levels are significantly greater in the estate sector where the prevalence of under nutrition is high. Thus, this review was undertaken to understand the potential role of lentils in the Sri Lankan diet and how lentils can potentially be utilized to meet the nutritional needs of Sri Lankans. The study was based on an extensive literature review and information obtained through personal interviews with key participants in the red lentil industry of Sri Lanka. It was evident that red lentils are a rich source of nutrients, especially micro-nutrients, but their bioavailability is poor due to the presence of multiple anti-nutritive factors such as protease inhibitors, phenolic compounds and phytates. Although bioavailability of nutrients can be enhanced by changing food processing techniques, fortification and bio-fortification, lentil cooking patterns in Sri Lanka pose difficulties in adopting changed food processing techniques and fortification. Thus, bio-fortification would be the most viable option for enhancing nutrient availability in lentils. Since Sri Lanka does not produce lentils, such initiatives may have to be undertaken in exporting countries or in collaboration with international agricultural research centres. Any strategic investments in breeding new lentil varieties with high bioavailability would provide exporting countries a unique competitive edge in export markets. Such improvements would meet the nutritional needs, not only of Sri Lankans, but also of millions other Asian consumers who face similar nutritional challenges.

Key words: Bioavailability, Consumption, Nutrition, lentils, Sri Lanka 


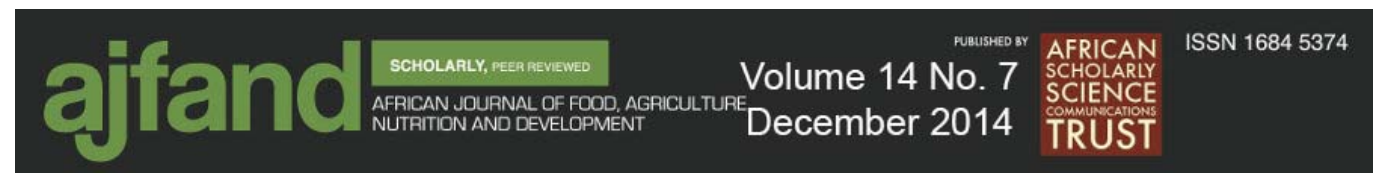

\section{INTRODUCTION}

Dietary deficiency of vitamins and minerals, which are needed in small amounts for various physiological functions, is known as micronutrient malnutrition [1]. Among the many micronutrient deficiencies, vitamin A, iron and iodine deficiencies are the prime concern in public health programs. Often referred to as "hidden hunger", micronutrient malnutrition has numerous adverse health consequences, such as impaired learning ability, continued and sustained loss of productivity, permanent mental disability, blindness, depressed immune system function and increased infant and maternal mortality $[2,3,4]$. Moreover, micronutrient malnutrition hinders socio-economic development and contributes to a vicious cycle of underdevelopment [4]. Micronutrient malnutrition is caused when the diet lacks diversity and in developing countries the main cause of undernutrition is poor diet diversity $[1,5]$.

According to the World Bank, Sri Lanka has relatively high prevalences of underweight children $(29.4 \%$ of children aged $0-5$ years in 2000$)$, children born with low birth weight (16.6\% in 2003), chronic energy deficiency (more than $33 \%$ of women in 2000 ), iron deficiency anemia (according to the WHO standards, severe among children aged 6-11 months and moderate among both children under 5 and women), vitamin A deficiency (sub-clinical vitamin A deficiency is $36.3 \%$ and clinical vitamin A deficiency is $0.8 \%$ among pre-school children in 1996) and iodine deficiency (prevalence of goiter among school children between 8-10 years is 20.9\%) [6]. According to this study, the rural and estate sectors ${ }^{1}$ are performing well below the national average. Although the problem of being underweight is more common among lower income groups, there is an increasing concern of being overweight among high income groups. Based on global standards, these nutrition related problems represent a serious public health concern in Sri Lanka.

As with all developing countries in South Asia, Sri Lanka relies heavily on a rice-based diet to meet daily energy and nutritional requirements. However, rice contains significant amounts of only eight amino acids. In this respect, lentils are an ideal dietary supplement for a rice-based meal because of their rich composition of essential amino acids. Thus, lentils are sometimes called "poor man's meat", referring to their high protein content and low price. This paper discusses the significance of lentils in the Sri Lankan diet with a special emphasis on their nutritional role and value. It aims to examine how lentils can be utilized to better meet the nutritional needs of Sri Lankans. This paper is based on an extensive literature review and information obtained through personal interviews with key participants in the red lentil industry of Sri Lanka.

\footnotetext{
${ }^{1}$ According to the classification adopted by the Department of Census and Statistics, Sri Lanka; the "urban sector" includes the areas governed by either Municipal or Urban Councils; the "estate sector" includes the plantation areas which have more than 20 acres and have more than 10 residential laborers and the residential areas which do not belong to the urban or estate sectors are defined as the "rural sector" [7].
} 


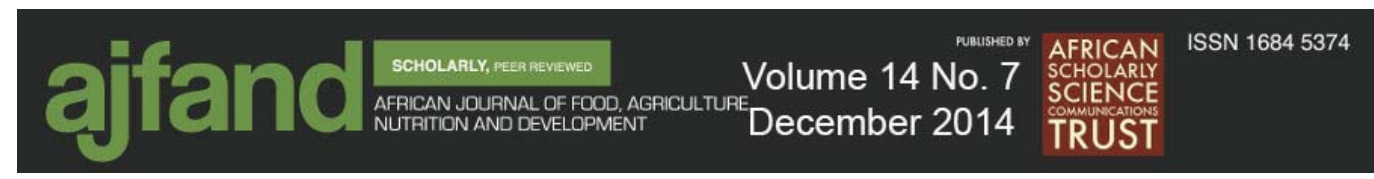

\section{SIGNIFICANCE OF LENTILS IN THE SRI LANKAN DIET}

Lentil (Lens culinaris Medic.) is a pulse crop which belongs to the family Leguminosae. Two main types of lentils - red and green - are grown in many parts of the world including India, Canada, Turkey, USA, Australia, China and Nepal as a short duration winter crop. The red lentil has an external seed coat that may vary from light grey through black to brown, or red, and a red internal seed coat. It is the predominant type grown around the world. Red lentils are usually decorticated and sold without splitting (football lentils) or as split lentils. Green lentils are consumed as whole lentils and have a green to brown external seed coat with a yellow seed. The decorticated and split lentils are usually known as dhal in the Asian region and are consumed as a side dish (curry) with a rice-based meal.

In Sri Lanka, the domestically grown pulses such as green gram (Vigna radiata) and cowpea (Vigna unguiculata) have been a main ingredient in traditional cuisine. However, following economic liberalization policies begun in 1977, culinary traditions changed significantly with the introduction of split red lentil in the domestic market. Consumption of red lentils expanded rapidly due to their cooking convenience and preference over traditional, domestically grown pulses. Consumers began referring to split red lentils by their export origin - an Indian province named Mysore, so that since 1977, red lentils have become known as Mysoor dhal and are now an integral component of Sri Lankan cuisine.

Although other countries within the South Asian region produce lentils in addition to their imports, in Sri Lanka climatic and environmental factors are not conducive to lentil production, hence the country is totally dependent on imports. According to the International Trade Centre, Sri Lanka is the third largest importer of lentils in the world. In 2010, Sri Lanka imported 134,340 tons of lentils (product classification - 071340) with a value of US\$ 129.6 million. In 2007, the government of Sri Lanka recognized lentils as one of the essential commodities and imposed a special commodity levy through the Special Commodity Levy Act No. 48 of 2007 [8]. This special levy was introduced to prevent price escalations of essential commodities in the domestic economy. Although the import levy varied over the years, it favoured the importation of whole lentils over split lentils. Complete dependence on lentil imports has significant implications on Sri Lankan food security. However, so far Sri Lanka has not made any progress in lentil production largely due to unfavorable weather and climatic conditions. Locally grown traditional legume crops have not been able to compete and production levels have declined (Figure 1). The inability to produce lentils, combined with increasing demand, has made Sri Lanka a prime target market for exporting countries $[9,10]$. 

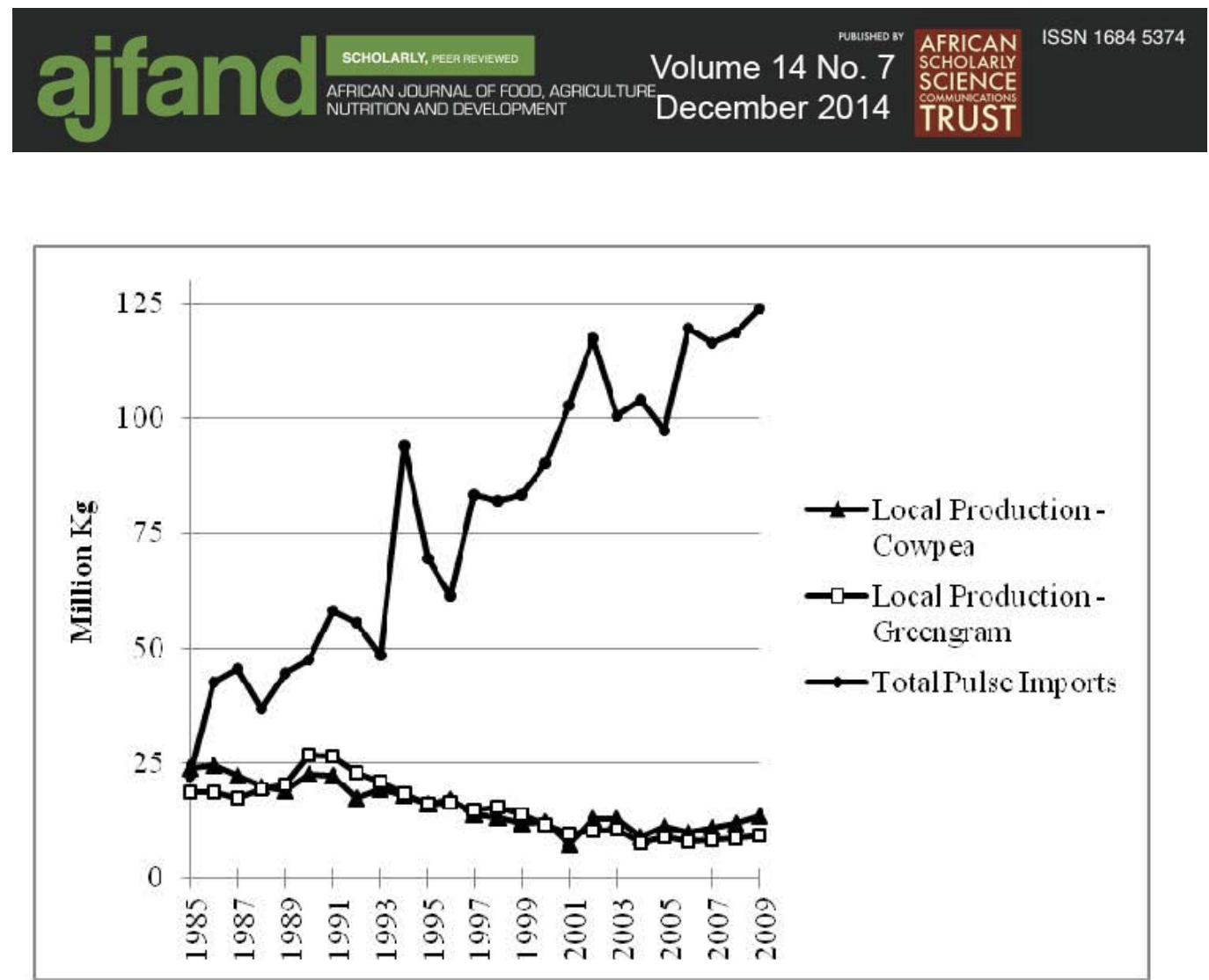

Figure 1: Domestic production and imports of pulses [11]

In Sri Lanka, green gram and cowpea are commonly consumed for breakfast after boiling but lentils are primarily cooked as a curry and eaten with a rice-based meal or with bread. Given their cooking convenience, lentils are consumed widely irrespective of income level. According to an income and expenditure survey in 2009/10, the average monthly per capita consumption level of pulses is 671.14 grams of which $70 \%$ comes from lentils (Table 1) [7]. Although both plant- and animal-based foods provide the daily protein requirement for Sri Lankans, it is clear that the level of consumption of plant-based protein sources is greater than other sources. Consumption levels show that animal-based food consumption is much lower in the rural and estate sectors than in the urban sector. According to the Department of Census and Statistics, on average a Sri Lankan household consumes $1.9 \mathrm{~kg}$ of lentils per month [7]. The estate sector has the greatest consumption levels of $3.0 \mathrm{~kg}$ whereas the other two sectors - urban and rural - have a relatively low monthly consumption of $1.8 \mathrm{~kg}$ each (Table 2 ). The unit price of lentils is low compared with all animal-based protein sources such as chicken, fish and beef and hence the accessibility of lentils is greater for the poor who are more vulnerable to nutrient deficiency. Thus, lentils as a plant-based protein source have a role to play in alleviating protein-energy and micronutrient malnutrition in Sri Lanka.

\section{NUTRITIONAL VALUE OF LENTILS}

The nutrient database of the United States Department of Agriculture (USDA) shows that lentils are rich in proteins and have 18 of the 20 amino acids including all 8 essential amino acids [12]. Lentils also provide essential minerals such as $\mathrm{Ca}, \mathrm{Fe}, \mathrm{Mg}, \mathrm{P}, \mathrm{K}, \mathrm{Na}$, $\mathrm{Zn}, \mathrm{Cu}, \mathrm{Mn}$, Se (Table 3). Thus, lentils continue to occupy an important place in the human diet, especially in developing countries, as a rich source of protein, vitamins and 


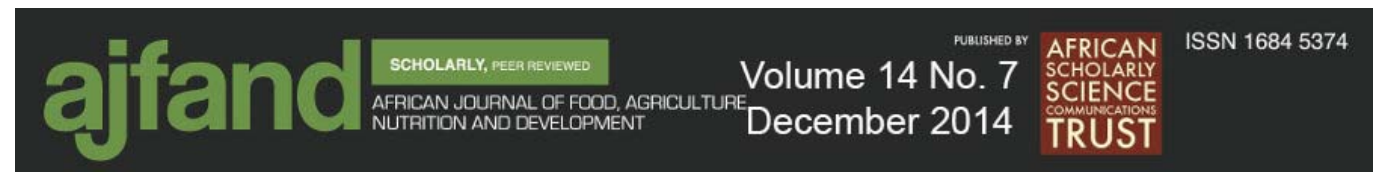

minerals. Lentils also provide other health benefits and promote general well-being due to their richness in protein, dietary fibre, soluble fibre, anti-oxidants, phytoestrogens and folate, and their low glycaemic index [13]. It has been reported that lentils are helpful in controlling Type II diabetes, lowering blood cholesterol levels and preventing coronary heart diseases and cancer $[13,14]$.

\section{PROBLEMS ASSOCIATED WITH LENTILS IN MEETING NUTRITIONAL NEEDS}

Although lentils are rich in nutrients, their bioavailability - the proportions of the total nutrients in lentils that are digested, absorbed and metabolized by normal pathways is limited due to the presence of multiple anti-nutritive factors such as protease inhibitors, phenolic compounds and phytates [15-17]. This is a common problem associated with many plant-based foods $[5,18,19]$. While these anti-nutritional factors create problems in nutrient absorption, they are also considered to play a beneficial role in preventing coronary heart disease and cancer [18].

Phytic acids contained in the protein bodies of the cotyledonous fraction of the lentil seed are the most common factor that lowers the absorption of protein, minerals and trace elements, especially iron, zinc and calcium [20 -24]. Phytic acid concentration in lentil seeds varies due to genotypic variation, climatic conditions, soil factors and other unexplained causes [25-27]. Similarly, the method of processing [15, 21, 22, 25, 28], food preparation techniques and other meal components [29] also influence the phytic acid concentration and other anti-nutrient factors in a meal.

The measurement of nutrient absorption depends on the subjects, meal type and method of estimation [29]. A study in Pakistan on the impact of traditional cooking on nutritional quality of lentils showed that steeping followed by boiling reduces the phytic acid content by $76 \%$ and improves protein utilization [25]. Another study in Chile has shown that cooking significantly increases protein digestibility in lentils [28]. A Bangladeshi study using malnourished children recovering from Shigellosis revealed a higher nitrogen absorption and improved nitrogen balance from a lentil based high protein diet [30]. By analyzing eight varieties of Canadian lentils, Wang et al. showed that cooking and dehulling significantly decreases the phytic acid content and increases the protein $(\mathrm{g} / \mathrm{Kg}$ dry matter) content in lentils [31]. In contrast, the USDA nutritional database [12] shows that cooking significantly decreases the protein content in lentils due to the water absorbtion but slightly increases it per unit of energy. Similarly, by discussing the potential role of plant-based sources in decreasing micronutrient malnutrition, Graham and Welch[ 5] and Welch and Graham[18] report a number of contradictory arguments on the influence of phytic acid on iron absorption .? Therefore, the results of these studies on protein and iron absorption should be interpreted carefully after considering the context within which the analyses have been made. 


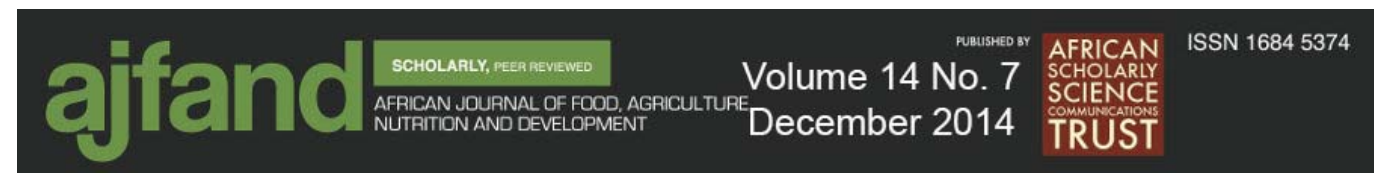

\section{ENHANCING THE BIOAVAILABILITY OF NUTRIENTS IN LENTILS}

Bioavailability of nutrients in plant-based food can be enhanced by changing food processing techniques, fortification and biofortification. It has been found that steeping and cooking, germination, cooking and drying significantly increase amino acid availability, protein digestibility and net protein utilization [24, 25, 28]. Similarly, soaking, germination and fermentation, and subsequent drying, dehulling and milling of germinated seeds substantially reduces the phytic acid content in lentils [21, 22]. However, in Sri Lanka, such cooking and processing techniques cannot be adopted as lentils available for consumption are already decorticated and split. Typically, these split lentils are consumed as a curry (cooked with salt and coconut milk) and the use of lentil flour in cooking is not practised in Sri Lanka. The split nature of lentils also does not allow soaking prior to cooking for a considerable time as it influences cooking quality.

The most effective way to remove phytic acid is enzymatic degradation [22, 32]. A reduction of phytic acid by $90 \%$ is said to increase the absorption by two fold and complete degradation would result in five-fold increase in absorption [22]. However, the study recommends that the molar ratio of phytic acid to iron be $<1$, preferably $<0.5$, to enhance iron absorption. Since a greater proportion of the lentils in Sri Lanka are processed - dehulled and split - it is important to examine the possibilities of decreasing the phytic acid concentration during processing by using enzymatic degradation (in $2010,83 \%$ of the red lentil imports were in the form of whole, un-skinned lentils). This requires extensive research and processors could work collaboratively with their suppliers and strengthen value chain performance through co-investments. Commercial interests will drive change only when the economic returns from doing so are positive; so the solution lies in public-private partnerships that extend along the whole chain from producer to consumer. In the case of Sri Lanka, this will require cross-border cooperation between commercial partners, government and development agencies.

\section{Fortification}

Addition of small amounts of essential vitamins and minerals to food is known as food fortification. Vitamin A, folic acid and iron are some of the nutrients used in food fortification programs. Although fortification of lentils has not been recorded, rice fortification ${ }^{2}$ is commonly being practised to meet nutritional needs of consumers; for example, the Philippines and Indonesia have adopted a rice fortification strategy to overcome micronutrient deficiencies [33]. Similarly, developed countries such as the U.S.A., Canada and Japan also fortify rice to provide additional nutrients. In this respect, there is a realistic possibility of fortifying lentils in Sri Lanka as more than $80 \%$ of the processing is carried out by one processor (personal communication with the Managing Director, Pulses Splitting \& Processing Industry (Pvt) Ltd., Sri Lanka). However, as FAO highlighted, any fortification strategy also has number of challenges that need to be addressed [34].

\footnotetext{
${ }^{2}$ Rice fortification involves making a small number of extruded rice pellets that are heavily fortified and added back in small amounts to regular rice. However, some countries use coating or dusting technology to fortfiy rice.
} 


\section{Bio-fortification}

Bio-fortification - the development of micronutrient rich food crops through plant breeding - has been considered as the most cost effective way of addressing micronutrient malnutrition [35-38]. There is great genetic potential in lentils to manipulate tissue nutrient concentrations through plant breeding [27]. Genetic manipulation may be possible to enhance the concentrations of micronutrients and promoter substances such as ascorbic acid and beta-carotene. Similar to micronutrient enrichment, there is also a possibility of enhancing the bioavailability of nutrients through breeding cultivars with lower concentrations of anti-nutritional factors such as phytic acid [26, 32]. However, some researchers argue that phytic acid reduction through plant breeding should be done only after careful consideration, as phytic acid plays a significant role in crop growth and human health $[5,36,39]$.

Since Sri Lanka does not produce lentils and its demand is fully met through imports, such research should be carried out in producer countries after reviewing the influence of phytic acid on nutrition. In the long-run, the development of lentils with greater levels of nutrient bioavailability would have the potential to provide a competitive edge for exporting countries so long as the value created by these improvements can be compensated for by the downstream components of the value chain - and ultimately by the consumer. Currently, Australia is the main exporter of red lentils to Sri Lanka with a share of nearly $50 \%$. Canada, the main competitor for Australian lentils in the Sri Lankan market, has already recognized the value of nutritional enhancement in developing its lentil industry and research on genetic improvement currently includes a focus on bio-fortification [40, 41]. Similarly, the International Food Policy Research Institute (IFPRI) has identified lentils as a potential crop to be included in stage two of its nutrient enhancement program [42].

Although investments on varietal development through breeding programs are costly, Brennan et al.[43] recommended that Australia needs a stronger domestic research program to capture the benefits arising from research carried out in International Agricultural Research Centers. By discussing the spill-over effects of international agricultural research on five crops - barley, durum wheat, chickpeas, faba beans and lentils - Brennan et al. [43, 44] clearly showed that Australia has developed its lentil industry primarily based on the genetic material obtained from the International Center for Agricultural Research in the Dry Areas (ICARDA) which has the global mandate for improvement of lentils. They highlighted that there is a great potential for Australia to collaborate with the Consultative Group on International Agricultural Research (CGIAR) and extend their research in breeding programs. Such collaborations would enable Australia to meet the nutritional needs of the main importing countries such as Sri Lanka while enabling the Australian lentil producers to be at par with or preferred to their competitors while benefiting the importing countries.

Similarly, the Copenhagen Consensus in 2008 has also raised the need for such interventions by developed country partners in improving the nutritional value of food that is consumed by developing countries[45]. Accordingly, investments on 


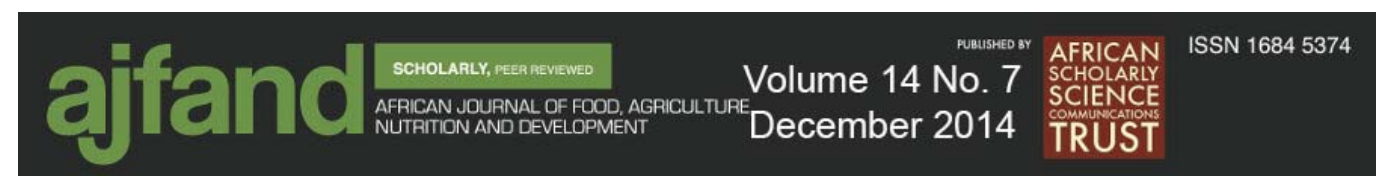

supplementation (rank 1), fortification (rank 3), biofortification (rank 5), deworming and other nutritional programs (rank 6) and community-based nutritional promotion programs (rank 9), should be the order of priority for international development partners in alleviating malnutrition in developing countries. However, according to Meenakshi, breeders must identify micronutrient rich lines that can be bred into local varieties, nutritional efficacy must be established, and finally both farmers and consumers must accept the new variety [38]. Ultimately, this would make such long-term investments cost effective. Some of these efforts are evident in successful biofortification schemes adopted for enhancing the provitamin $\mathrm{A}, \mathrm{Fe}, \mathrm{Zn}$ in crops such as sweet potato, rice, wheat, cassava, bean and pearl milliet [46].

\section{CONCLUSIONS}

Sri Lankans depend heavily on a cereal-lentil based diet to meet their daily nutritional needs, but anti-nutritional factors in lentils hinder the absorption of nutrients. As all lentils are imported, enhancing the bioavailability of nutrients in lentils exported to Sri Lanka has the potential to provide a competitive edge for exporting countries. However, any intervention focused on nutritional improvement should focus on the entire value chain from seed production through to consumption, and should be based on scientific evidence gathered through well-designed studies. Such studies should focus on determining nutrient availability and absorption levels considering traditional cooking practices in Sri Lanka, and be informed by consumer research. Results could ultimately provide exporters of lentils with a competitive edge in lentil export markets, not only in Sri Lanka but also in many other South Asian countries that face similar nutritional challenges. 


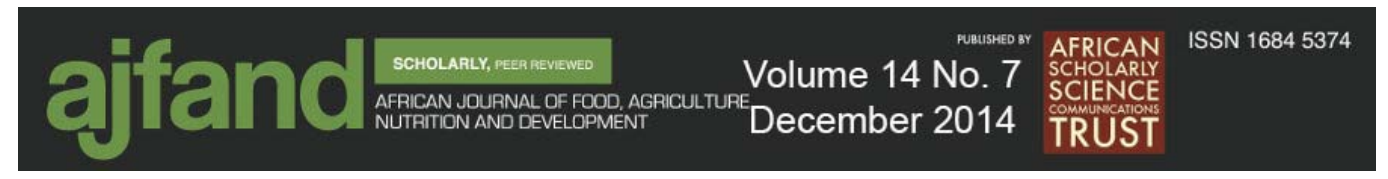

Table 1: Average monthly consumption - 2009 (Grams/Person/Month)

\begin{tabular}{|l|l|l|}
\hline Type & Quantity (Grams) & \% of Total \\
\hline Dhal (Lentils) & 470.16 & 70 \\
\hline Green gram & 55.34 & 8 \\
\hline Gram & 53.31 & 8 \\
\hline Cowpea & 19.69 & 3 \\
\hline Soya & 7.63 & 1 \\
\hline Soya meat & 47.56 & 7 \\
\hline Other pulses & 19.45 & 3 \\
\hline Total & 671.14 & 100 \\
\hline
\end{tabular}

Table 2: Average monthly household consumption levels by sector - 2009

\begin{tabular}{|c|c|c|c|c|c|}
\hline Item & Unit & Sri Lanka & Urban & Rural & Estate \\
\hline Dhal (Lentils) & $\mathrm{Kg}$ & 1.9 & 1.8 & 1.8 & 3.0 \\
\hline Chicken & $\mathrm{Kg}$ & 1.0 & 1.6 & 0.9 & 1.0 \\
\hline Beef & Grams & 318.1 & 506.5 & 303.9 & 44.0 \\
\hline Fish - Tuna ${ }^{a}$ & Grams & 582.4 & 917.1 & 544.0 & 305.5 \\
\hline Dried fish $^{b}$ & Grams & 621.7 & 545.2 & 647.8 & 409.7 \\
\hline Eggs & Number & 10.7 & 14.5 & 10.0 & 10.5 \\
\hline Cow milk & $\mathrm{ml}$ & 549.2 & 556.3 & 528.5 & 860.2 \\
\hline Milk powder & $\mathrm{Kg}$ & 1.3 & 1.9 & 1.2 & 1.2 \\
\hline
\end{tabular}

${ }^{a}$ Includes only Skipjack tuna (Katsuwonus pelamis) and Yellowfin tuna (Thunnus albacores)

${ }^{\mathrm{b}}$ Includes only dried anchovy (Stolephorus sp.) and Scomberoides commersonianus 


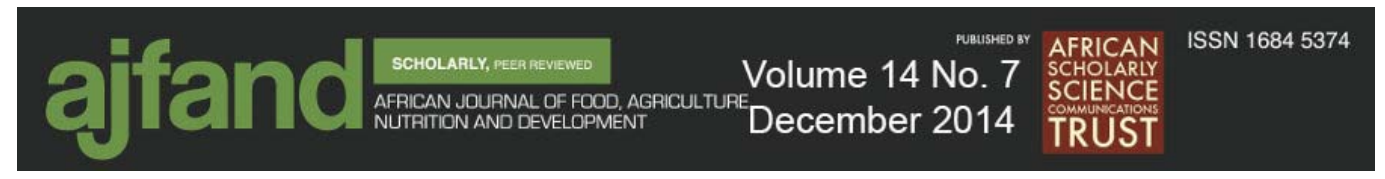

Table 3: Nutritional composition of cooked ${ }^{1}$ lentils (Value per 100 grams)

\begin{tabular}{|l|l|l|l|}
\hline Nutrient & Cooked & Nutrient & Cooked \\
\hline Energy (kcal) & 114 & Vitamins & \\
\hline Protein (g) & 9.02 & Vitamin C (mg) & 1.5 \\
\hline Total lipid (fat) $(\mathrm{g})$ & 0.38 & Thiamin $(\mathrm{mg})$ & 0.169 \\
\hline $\begin{array}{l}\text { Fiber, total dietary } \\
(\mathrm{g})\end{array}$ & 7.9 & Riboflavin $(\mathrm{mg})$ & 0.073 \\
\hline Minerals & & Niacin $(\mathrm{mg})$ & 1.06 \\
\hline Calcium (mg) & 19 & $\begin{array}{l}\text { Pantothenic acid } \\
\text { (mg) }\end{array}$ & 0.638 \\
\hline Iron $(\mathrm{mg})$ & 3.33 & Vitamin B-6 (mg) & 0.178 \\
\hline Magnesium (mg) & 36 & Folate (mcg) & 181 \\
\hline Phosphorus (mg) & 180 & Choline (mg) & 32.7 \\
\hline Potassium (mg) & 369 & Vitamin A, (mcg) & 0 \\
\hline Sodium (mg) & 238 & Carotene, beta (mcg) & 5 \\
\hline Zinc (mg) & 1.27 & Vitamin A, (IU) & 8 \\
\hline Copper (mg) & 0.251 & Vitamin E (mg) & 0.11 \\
\hline Manganese (mg) & 0.494 & Vitamin K (mcg) & 1.7 \\
\hline Selenium (mcg) & 2.8 & & \\
\hline
\end{tabular}

${ }^{1}$ Cooked, boiled with salt 


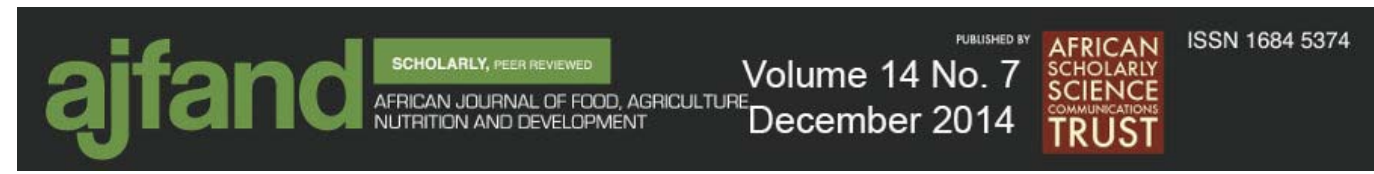

\section{REFERENCES}

1. FAO and ILSI. Food and Agriculture Organization of the United Nations and International Life Sciences Institute. Preventing Micronutrient Malnutrition: A Guide to Food-based Approaches - A Manual for Policy Makers and Programme Planners, ISLI, Washington, D.C. 1997.

2. Kennedy E, Mannar $\mathbf{V}$ and $\mathbf{V}$ Lyengar Alleviating hidden hunger: approaches that work. IAEA Bulletin 2003; 45(1): 54-61.

3. Kennedy G, Nantel G and P Shetty The scourge of "hidden hunger": global dimensions of micronutrient deficiencies. fna | ana 2003; 32: 8-16.

4. WHO and FAO. World Health Organization and the Food and Agriculture Organization of the United Nations. Guidelines on Food Fortification with Micronutrients. WHO and FAO. Rome, 2006.

5. Graham RD and RM Welch Breeding for Staple Crops with High Micronutrient Density. Working papers on Agricultural Strategies for Micronutrients, No. 3, International Food Policy Research Institute, Washington D.C. 1996.

6. World Bank. Malnutrition in Sri Lanka: Scale, Scope, Causes and Potential Response, Report No. 40906-LK, World Bank, Human Development Unit, South Asia Region, 2007.

7. Department of Census and Statistics of Sri Lanka. Household Income and Expenditure Survey 2009/10 - Preliminary Report, Colombo: Department of Census and Statistics. 2011.

8. Parliament of the Democratic Socialist Republic of Sri Lanka. Special Commodity Levy Act, No. 48 of 2007, Supplement to Part II of the Gazette of the Democratic Socialist Republic of Sri Lanka of October 19, 2007. Parliament of the Democratic Socialist Republic of Sri Lanka, Sri Lanka 2007.

9. Mercantile Consulting. Overview of Canadian lentil export markets, (Accessed on $1^{\text {st }}$ March 2011). http://www.saskpulse.com/media/pdfs/market-overviewlentil.pdf. 2005.

10. Agblor K The cropportunity strategy for red lentil. PulsePoint 2006; 6: 26-27.

11. Department of Agriculture of Sri Lanka. Database, Department of Agriculture: Peradeniya. 2010.

12. United States Department of Agriculture (USDA). Nutrient database, (Accessed on $1^{\text {st }}$ March 2011). http://www.nal.usda.gov/fnic/foodcomp/search/

13. Pulse Australia. Health Benefits of Pulses. Australian Pulse Bulletin 4: Pulse Australia. 2008. 


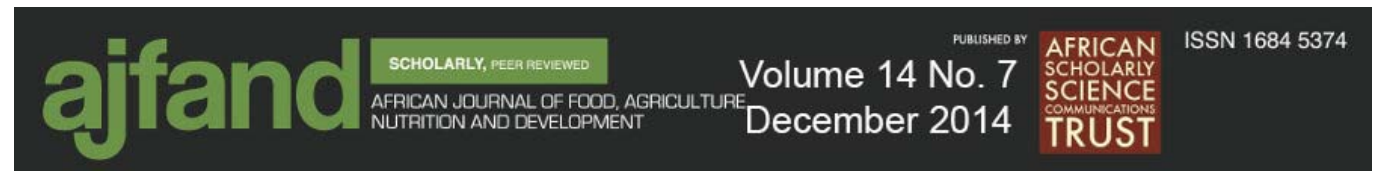

14. Leterme $\mathbf{P}$ Recommendation by Health Organizations for Pulse Consumption, Br. J. Nutr. 2002; 88: S239-S242.

15. Ghavidel RA and J Prakash The Impact of Germination and Dehulling on Nutrients, Antinutrients, In-vitro Iron and Calcium Bioavailability and in Vitro Starch and Protein Digestibility of some Legume Seeds. Int. J. Food. Sci. and Technol., 2007; 40: 1292-1299.

16. Urbano G, Porres JM, Frias $\mathbf{J}$ and $\mathbf{C}$ Vidal-Valverde Nutritional Value. In: Yadave SS. D McNeil and PC Stevenson (Eds). Lentil: An Ancient crop for Modern Times, Netherlands: Springer, 2007: 47-94.

17. Sulieman MA, Hassan AB, Osman GA, EI Tyeb MM, EI Khalil EAI, EI Tinay AH and EE Babiker Changes in total protein digestibility, fractions content and structure during cooking of lentil cultivars, Pakistan J. Nutr. 2008; 7(6): 801-805.

18. Welch RM and RD Graham Breeding for micronutrients in staple food crops from a human nutrition perspective. J. Exp. Bot. 2004; 55: 353-364.

19. Gibson RS, Perlas $\mathbf{L}$ and $\mathbf{C}$ Hotz Improving the bioavailability of nutrients in plant foods at the household level, Proc. Nutr. Soc., 2006; 65: 160-168.

20. Lynch SR, Beard JL, Dassenko SA and JD Cook Iron absorption from legumes in humans, Am. J. Clin. Nutr. 1984; 40: 42-47.

21. Sandberg A Bioavailability of minerals in legumes, Br J Nutr 2002; 88: 281-285.

22. Hurrell RF Influence of vegetable protein sources on trace element and mineral bioavailability. J. Nutr. 2003; 133: 2973S-2977S.

23. Sahuquillo $\mathbf{A}$, Barber $\mathbf{R}$ and $\mathbf{R}$ Farrè Bioaccessibility of calcium, iron and zinc from three legume samples, Food 2003; 47(6): 438-441.

24. Urbano G, Lopez-Jurado M, Hernandez J, Fernandez M, Moreu M, Frias J, Diaz-Pollan C, Prodanov $M$ and C Vidal-Valverdef Nutritional assessment of raw, heated, and germinated lentils. J. Agr. Food Chem. 1995; 43: 1871-1877.

25. Manan F, Hussain T, Alli I and P Iqbal Effect of cooking on phytic acid content and nutritive value of Pakistani peas and lentils, Food Chem. 1987; 23: 81-87.

26. Thavarajah P, Thavarajah D and A Vandenburg Low phytic acid lentils (Lens culinaris L.): A potential solution for increased micronutrient bioavailability, $J$. Agr. Food Chem. 2009; 57: 9044-9049.

27. White PJ and MR Broadley Biofortification of crops with seven mineral elements often lacking in human diets - iron, zinc, copper, calcium, magnesium, selenium and iodine. New Phytologist 2009; 182: 49-84. 


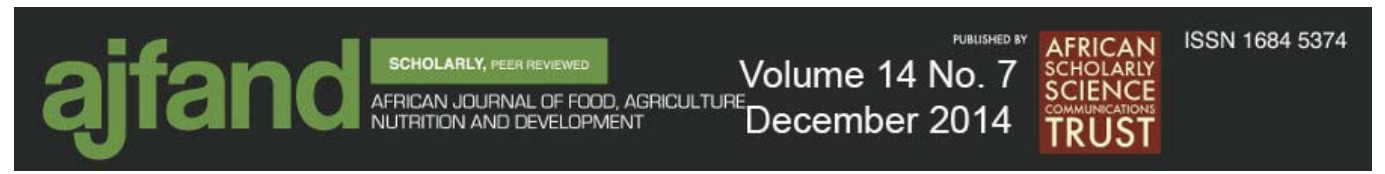

28. Estévez AM, Castillo E, Figuerola F and E Yaiqez Effect of processing on some chemical and nutritional characteristics of pre-cooked and dehydrated legumes, Plant Food Hum. Nutr. 1997; 41: 193-201.

29. Graham RD, Welch RM and HE Bouis Addressing micronutrient malnutrition through enhancing the nutritional quality of staple foods: principles, perspectives and knowledge gaps. Adv. Agron. 2001; 70: 77-142.

30. Hossain MI, Islam MM, Wahed MA, Khatun M and I Kabir Lentil-based high protein diet is comparable to animal-based diet in respect to nitrogen absorption and nitrogen balance in malnourished children recovering from shigellosis. Asia Pac. J. Clin. Nutr. 2009; 18(1): 8-14.

31. Wang N, Hatcher DW, Toews R and EJ Gawalko Influence of cooking and dehulling on nutritional composition of several varieties of lentils (Lens culinaris), Int. J. Food Sci. Technol. 2009; 42: 842-848.

32. Raboy V Progress in breeding low phytate crops. J. Nutr. 2002; 503S-505S

33. Dexter PB Rice Fortification for Developing Countries. United States Department of Agriculture, USA. 1998.

34. FAO. Food and Agriculture Organization of the United Nations. Food Fortification: Technology and Quality Control, FAO Food and Nutrition Paper No. 60, FAO, Rome: 1996.

35. Bouis HE Plant breeding: A new tool for fighting micronutrient malnutrition. $J$. Nutr. 2002; 491S-494S.

36. Bouis HE Micronutrient fortification of plants through plant breeding: Can it improve nutrition in man at low cost? Proc. Nutr. Soc. 2003; 62: 403-411.

37. Nestel P, Bouis HE, Meenakshi JV and W Pfeiffer Biofortification of staple food crops. J. Nutr. 2006; 136: 1064-1067.

38. Meenakshi JV Cost Effectiveness of Biofortification. Best Practice Paper: New Advice from CC08, Denmark: Copenhagen Consensus Center. 2009.

39. Welch RM Breeding strategies for biofortified staple plant foods to reduce micronutrient malnutrition globally. J. Nutr. 2002; 495S-499S.

40. Saskatchewan Pulse Growers. Pulse Days "Tools for Success". Canada: Saskatchewan Pulse Growers. 2010.

41. Glahn R and B Vandenburg Saskatchewan's competitive advantage biofortification, PulsePoint Magzine 2011; 18-19. 


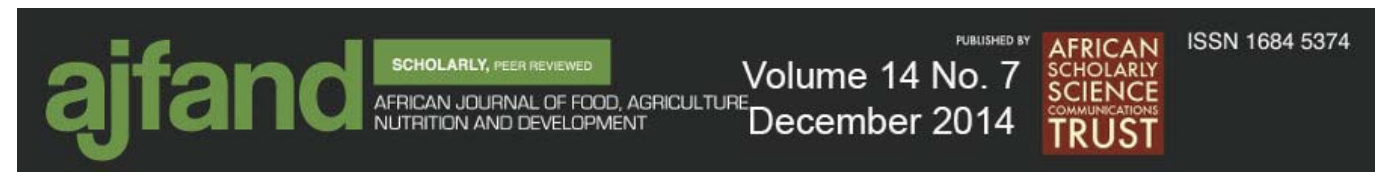

42. IFPRI. International Food Policy Research Institute. Harnessing Agricultural Technology to Improve the Health of the Poor: Plant Breeding to Combat Micronutrient Deficiency. (Accessed on 12 ${ }^{\text {th }}$ April 2012). http://www.ifpri.org/sites/default/files/publications/biofort.pdf. 2002.

43. Brennan JP, Aw-Hassan A, Quade KJ and TL Nordblom Impact of ICARDA Research on Australian Agriculture, Economic Research Report No. 11, NSW Agriculture, Wagga Wagga, Australia, 2002.

44. Brennan JP, Aw-Hassan A, Quade KJ and TL Nordblom Influence of spillovers to Australia on impacts of the International Center for Agricultural Research in the dry areas. Food Policy 2003; 28: 471-485.

45. Copenhagen Consensus Center. Copenhagen Consensus 2008 - Results. Denmark: Copenhagen Consensus Center, 2008.

46. Bouis, HE and RM Welch Biofortification - A sustainable agricultural strategy for reducing micronutrient malnutrition in the global south. Crop Sci. 2010; 50: S20-S32. 